\title{
Скрипник Тетяна
}

ORCID iD 0000-0002-8511-4984

доктор психологічних наук, старший науковий співробітник, професор кафедри спеціальної психології, корекційної та інклюзивної освіти,

Інститут людини,

Київський університет імені Бориса Грінченка вул. Маршала Тимошенка, 13-Б, 04212 Київ, Україна, t.skrypnyk@kubg.edu.ua

\section{ПІДГОТОВКА ОСВІТНЬОГО СЕРЕДОВИЩА ДО ІНКЛЮЗИВНОГО ПРОЦЕСУ У ЗАКЛАДАХ ЗАГАЛЬНОЇ СЕРЕДНЬОЇ ОСВІТИ}

В статті розкривається сутність иілеспрямованої та послідовної підготовки освітнього середовища до інклюзивного навчання у закладах освіти. Автор розкриває обмежений $i$ суперечливий характер поняття «інклюзивне освітнє середовище» в украйнських нормативно-правових та навчально-методичних розробках; представляє міжнародні орієнтири, за якими освітнє середовище набуває таких характеристик, як: безперешкодне, стимулююче, підтримувальне, розвивальне для усіх учнів. Автор ретельно аналізує зміст та структурні компоненти стратегії "Класний менеджмент», спрямованої на позитивне перетворення освітнього середовища для успіху кожного учасника освітнього процесу. Представлено дослідження щуодо впровадження стратегії «Класний менеджмент» в освітній процес, у якому взяли участь сім закладів освіти. Метою дослідження було здійснити позитивні перетворення в освітньому середовищі закладів освіти як підгрунтя впровадження ефективного інклюзивного навчання. Отримані результати засвідчили дієвість стратегї «Класний менеджмент», що позитивно перетворюе освітне середовище $i$ сприяе розбудові грамотного інклюзивного процесу.

Ключові слова: діти з особливими освітніми потребами, інклюзивне навчання, інклюзивне освітнє середовище, класний менеджмент.

(C) Скрипник Т., 2020 p.

https://doi.org/10.28925/2312-5829.2020.1.10 
Вступ. На сьогодні інклюзивні процеси в українській освіті мають характер непродуманості та фрагментарності. На наш розсуд, головними перешкодами впровадження справжньої інклюзивної освіти є: брак стратегії іiі розвитку, що уможливило б осмислену, цілеспрямовану і послідовну розбудову інклюзивних процесів; неправильне розуміння суті основних положень інклюзивної освіти (з огляду на міжнародні стандарти); невідповідність організаційних питань, а також нормативно-правового, кадрового, навчально-методичного, фінансового забезпечення інклюзії в освіті.

Прикладом невідповідності уявлення про суть основних положень інклюзивної освіти є тлумачення поняття «інклюзивне освітнє середовище» в українській нормативно-правовій базі та навчально-методичних розробках.

За законом України «Про освіту» (2017) термін «інклюзивне освітнє середовище» конкретизується як сукупність умов, способів і засобів їх реалізації для спільного навчання, виховання та розвитку здобувачів освіти з урахуванням їхніх потреб та можливостей. На жаль, подані у визначені поняття «умови, способи і засоби їх реалізації» не мають пояснення, тому їх тлумачення у розробках науковців і практиків є неузгодженим і суперечливим.

У наукових статтях, присвяченій розбудові інклюзивного освітнього середовища, автори подають такі неупорядковані й різнопланові напрями роботи, як: архітектурні перетворення, розроблення адаптованих програм, впровадження спеціального матеріально-технічного забезпечення, позитивної атмосфери у класі, правил спілкування, психологічної підтримки тощо (Талдонова, 2018; Коваль, 2018 та ін.).

Важливо також підкреслити, що орієнтир на «інклюзивне освітнє середовище» не став обов'язковою умовою у процесі розбудови інклюзивного навчання у закладах освіти України. Так, наприклад, у наявних індивідуальних програмах розвитку (ІПР) - головному документу для інклюзивного навчання дитини з ООП, взагалі не йдеться про інклюзивне освітне середовище, натомість у розділі «Адаптація» (ІПР для закладів загальної середньої освіти), або «Адаптація і 
ISSN Online: 2312-5829 Освітологічний дискурс, 2020, № 1 (28) модифікація освітніх програм» (IПР для закладів дошкільної освіти) зустрічаємо такий вислів, як «Пристосування середовища», який містить перелік таких показників, як: доступність, інтенсивність освітлення, рівень шуму, приміщення для усамітнення.

У навчально-методичному посібнику для працівників інклюзивно-ресурсних центрів (Організаційно-методичні засади, 2018), також не знаходимо орієнтиру на інклюзивне освітнє середовище, проте йдеться про облаштування «просторовофізичного середовища» Серед складників цього середовища названо: доступність приміщень; застосування спеціального сидіння (для дітей з порушеннями опорнорухового апарату); режим дня; організація додаткових перерв; використання спеціальних підручників; особливе розміщення дитини у класі неподалік від учителя (для дитини з порушеннями інтелектуального розвитку); поділ класу на зони, у тому числі - релаксаційну як місце усамітнення і відпочинку (наприклад, для дитини 3 розладами аутистичного спектра); використання візуальних стимулів; створення ситуацій успіху; уповільнення темпу роботи та контроль за динамікою втомлюваності дитини (для дітей з затримкою психічного розвитку) тощо. Слід зазначити, що окрім відсутності логіки подання структурних компонентів цього середовища та необхідного обгрунтування їх доречності, у такому викладі матеріалу усю увагу сконцентровано на дітях з ООП, через що порушується головна ідея інклюзивного навчання - створення середовища, спільного для усіх дітей як простору рівних можливостей.

Звертаємо також увагу на обмежений і невідповідний зміст характеристик інклюзивного освітнього середовища в україномовних джерелах; найбільш вживаним означенням тут є «безпечне», що ніяким чином не відображає новаторські підходи і відповідні вимоги до розбудови простору рівних можливостей.

Узагальнення наявних нормативно-правових та навчально-методичних матеріалів дає змогу констатувати, що поняття «інклюзивне освітнє середовище» представлено невизначено, сумбурно і суперечливо. Відсутність чіткого змісту та певних вимог до організації освітнього простору позначається на практиці тим, що не середовище підлаштовують до дитини, а дитина з ООП має підлаштовуватися до 
наявного середовища. За такого підходу фахівці виявляють некомпетентність як щодо розуміння інклюзивного навчання, так і його реалізації.

Мета статті - розкрити можливості інклюзивної стратегії «Класний менеджмент» в процесі створення відповідного та безперешкодного освітнього середовища для дітей 3 особливими освітніми потребами у закладах загальної середньої освіти як головної умови успішного інклюзивного навчання.

В розробленій у 2016 р. Концепції Нової української школи знаходимо характеристики освітнього середовища, які відповідають міжнародним зразкам. Так, названо, що сучасне середовище має бути творчим і охоплювати: просторовопредметне оточення, програми та засоби навчання. Йдеться також про планування i дизайн освітнього простору, що грунтується на особистісно-орієнтованій моделі освіти. Це конкретизується у спрямованості на: розвиток дитини і мотивації іiі до навчання, становлення «педагогічки партнерства» як взаємодії та співпраці між учителем, учнем і батьками, що передбачає: повагу до особистості, довіру у стосунках, рівність сторін, розподілене лідерство. На жаль, закарбовані у Концепції позиції не знайшли свого втілення у розробках, що стосуються інклюзивного навчання.

Необхідність звертати увагу на ресурси середовища підкреслено у новому орієнтирі до розбудови фахової допомоги для дітей з ООП - Міжнародній класифікації функціонування (МКФ). В МКФ зазначено, що фактори середовища впливають на всі складові функціонування та обмеження життєдіяльності; йдеться також про урахування системи факторів: від найближчого середовища особи до загального (Міжнародна класифікація функціонування, 2018).

Приділення уваги відповідній організації освітнього простору стало чинником успішної реалізації інклюзивного навчання у низці країн світу (США, Нідерландах, Фінляндії, Польщі та ін.). Так, наприклад, в США щодо стратегій перетворення освітнього середовища частіше за все вживають такі терміни, як «універсальний дизайн та розумне пристосування», «середовище 3 найменшими обмеженнями» (The Least Restrictive Environment, LRE), а також «Класний менеджмент». Серед цих 
ISSN Online: 2312-5829 Освітологічний дискурс, 2020, № 1 (28) понять тільки «Універсальний дизайн» (трохи рідше - «розумне пристосування) можна зустріти в українській нормативно-правовій базі, i деяких матеріалах, розроблених науковцями, методистами і практиками. Два інших поняття не знайшли свого місця в методичному, організаційному і практичному вимірах інклюзивного навчання в Україні.

«Середовище $з$ найменшими обмеженнями» (LRE) - це підхід, що передбачає максимальну ступінь участі осіб з ООП в освітньому процесі разом з однолітками у закладах освіти. При цьому, базовим моментом при обговоренні LRE має бути найвідповідніше середовище та допомога, необхідна щодо певної дитини з ООП для досягнення їі успіху у загальноосвітньому просторі. Цей підхід передбачає систему підтримки та послуг, що охоплюють: необхідні інструменти та матеріали; акомодацію й модифікацію освітнього процесу; рівень компетентності педагогічного колективу: особистісно спрямовані практики, що дають змогу усім учням мати доступ до спільного освітнього простору. Такий підхід демонструє високий рівень компетентності й відповідальності педагогічного колективу, адже сприяє ефективному освітньому процесу дітей з ООП, а також їхніх нормотипових однолітків.

Високого рівня компетентності, відповідальності, творчого начала і віри у можливості дітей вимагає від фахівців і стратегія перетворення освітнього середовища «Класний менеджмент». Цьому підходу ми приділимо найбільшу увагу у статті, адже, на наш розсуд, це найбільш доступна стратегія для впровадження на рівні простору закладу освіти, що уможливлює ефективне керування класним колективом, створює позитивну атмосферу між всіма учасниками освітнього процесу, сприяє досягненню найнеобхідніших цілей для особистісного та соціального зростання учнів, а також їхній академічній успішності.

Аналіз останніх досліджень і публікацій. Вагомим дослідженням у плані систематизації й узагальнення результатів втручання з використанням стратегії КМ став проведений мета-аналіз, що поєднав 54 досліджень, опублікованих за 10 років (Korpershoek at al, 2018). За цим мета-аналізом було зроблено висновок про те, що стратегія КМ підвищує навчальні, поведінкові, соціально-емоційні показники усіх 
учнів класу 3 інклюзивною формою навчання. Встановлено також причиннонаслідкову залежність, за якою покращення соціальних i емоційних навичок позитивно впливає на різноманітні результати освітньої діяльності для кожного учня. Підкреслено, що впровадження стратегії КМ - це шлях, який вимагає виходу за межі стереотипів і багато у чому залежить від підтримки нововведень 3 боку педагогічного колективу усього закладу освіти, ставлення до цього як до спільної справи. Головний висновок, зроблений дослідниками - тільки за умови налагодженого ефективного керування класним колективом зростає рівень якості освітнього процесу.

В іншому дослідженні було доведено, що впровадження стратегії КМ сприяє запобіганню асоціальної (проблемної) поведінки у класі, натомість слугує становленню довірливої й підтримувальної атмосферу серед учнів (Collier, 2018).

Основною перевагою у стратегії КМ називають також створення ефективних стосунків на рівні «вчитель-учень», що відіграє найважливішу роль у покращенні освітнього середовища, а також розкритті нових можливостей учнів, їхнього соціального інтелекту й саморегуляції (Kumar, 2019). Процес створення таких стосунків є продуманим з боку вчителя і базується на методах, що мають визнану ефективність, наприклад, методі саморегульованого навчання, навчання за умови співробітництва між вчителем та учнями, з одного боку, а з іншого, самими учнями.

У монографії (Скрипник, 2019) нами було систематизовано міжнародну практику впровадження КМ у закладах освіти. Ключовий компонент ефективного освітнього середовища, за цією стратегією - його продуманість та упорядкованість. Забезпечення структурованого освітнього середовища дає багато переваг для вчителя та учнів. Це відчуття безпеки, чіткість та зрозумілість поведінки у відповідності до певних зон, передбачуваність діяльності, що так важливо для порядку в класі.

Сутність КМ полягає у розкритті й впровадженні таких груп середовищних ресурсів, як: 
ISSN Online: 2312-5829 Освітологічний дискурс, 2020, № 1 (28)

1. Предметно-просторові (розроблення та застосування засобів перетворення простору класної кімнати (фізичного простору);

2. Організаційно-смислові (структуроване і своєчасне подання оптимально відібраних наочних засобів інструктивної спрямованості - система візуальних засобів);

3. Соціально-психологічні (встановлені соціальні ролі, позиція вчителя, його компетентність та особистісний потенціал, вміння працювати у команді 3 учнями, батьками, іншими педагогами).

Важливі складники предметно-просторових ресурсів - одномісні парти (наявність яких дає змогу гнучко змінювати формат процесу навчання, коли учень набуває здатності до самостійної діяльності, взаємодії у парі та мікрогрупі), стелажі, ширми, шафи, килими; «Куток заспокоєння»; Куток дітей (персоніфікація класного колективу та життя класу); Куток вчителя; різні зони (ігрова, сенсорна тощо). Особливою характеристикою сучасного освітнього простору має стати його повна відкритість, доступність для дітей: шафи і полиці з відкритими комірками, у яких розміщено коробки (контейнери, папки) з необхідними для практичної роботи учнів матеріалами та/або особисті речі.

Завдяки продуманим організаційно-смисловим ресурсам педагоги разом 3 дітьми можуть створити середовища, яке: 1) насичене інформацією, що відповідає віку дітей і є значущою для них, і водночас - 2) затишне, особистісно орієнтоване, у якому формується причетність кожного учня до життя класу, сприятливе для особистісного та міжособистісного розвитку учнів; становлення почуття колективної відповідальності. Засоби наочності оформлюють та упорядковують на певних стендах, дошках, стінах, дверях так, щоб вчителю було зручно задіювати їх в освітньому процесі, а учням - орієнтуватися на них. Серед таких засобів можуть бути, наприклад: ефектно представлені розклад, розроблені вчителем спільно 3 учнями класні правила і процедури, які ретельно відпрацьовані і мають змінний характер, в залежності від ступеню освоєння їх учнями; дошка оголошень: календар, обов’язки учнів (за кожним з яких закріплюється черговий так, щоб кожна дитина протягом тижня відчувала причетність до життя класу), очікування вчителя та учнів,

Скрипник Т., 2020 p. 
діаграми погоди, картка присутності учнів, об’яви для батьків; стенд «Зірки тижня» (представлення дітей, які досягли успіхів у навчанні та у соціальній сфері); стенд «Рівень поведінки» тощо.

Соціально-психологічні ресурси охоплюють такі позиції, як: нова, сучасна позиція Вчителя (рівноцінність та рівнозначність у стосунках з учнями і батьками; налагодження «відкритої» продуктивної комунікацію, спрямованість на розкриття потенціалу кожної дитини); розвинені соціальні ролі учнів як особистостей, які впливають на перебіг освітньої діяльності, турбуються один за одного і підтримують того, хто цього потребує.

Таким чином, стратегія КМ уможливлює створення сучасного, яскравого, привабливого і дружнього для усіх учнів освітнього середовища, у якому кожний 3 них може розкрити свій потенціал, розвинути свої соціальні й особистісні якості, мати високі академічні досягнення.

Результати дослідження. Нами було проведено дослідження, спрямоване на підготовку освітнього середовища до інклюзивного процесу. Протягом 5 років (2015-2019) у цьому дослідженні взяли участь педагогічні колективи 7 закладів загальної середньої освіти (5 державних і два приватних).

Мета цієї дослідницької діяльності була - впровадити стратегію «Класний менеджмент» в освітній процес закладу освіти задля позитивних перетворень в освітньому середовищі і впровадженні ефективного інклюзивного навчання. Це передбачало: зменшення стресогенності середовища для учнів 3 ООП; впровадження структурованості, мобільності і доступності щодо предметнопросторових ресурсів; особистісна та соціальна орієнтованості при оформленні візуальних стимулів; реалізація партнерських стосунків між вчителем, учнями та їхніми батьками тощо.

Головний акцент роботи припадав на підготовчий період, коли треба було здійснити відповідні перетворення, з одного боку, налаштувати педагогів стосовно нової позиції у класі, а також продумати етапи введення дітей з ООП до створеного освітнього середовища так, щоб цей перехід не був для них травматичним, а 
ISSN Online: 2312-5829 Освітологічний дискурс, 2020, № 1 (28) навпаки - вони потрапили у місце, де їм все знайомо: режим, правила перебування, алгоритм власних дій, стосунки між ними і педагогами, ними й іншими учнями тощо.

Слід сказати, що через різні обставини об’єктивного і суб’єктивного характеру, нам лише частково вдалося реалізувати задум цієї дослідницької роботи. При цьому, за експертними оцінками педагогічних колективів, навіть не повний обсяг досягнених змін значно покращив початок інклюзивного навчання (ц порівнянні 3 ситуацією попередніх років, коли не здійснювали перетворення за стратегією КМ). Зі свого боку команда організаторів та експертів цього дослідження відзначила особливий успіх у тих двох школах (одна з них була державна, а одна приватна), педагогічні колективи яких виявили щиру зацікавленість запропонованим підходом i долучалися до підготовчої роботи не як виконавці, а як справжні партнери, 3 ентузіазмом, креативними пропозиціями, бажанням перетворити середовище на краще і досягнути більшого успіху у процесах навчання і розвитку учнів.

Висновки. Орієнтир на технології та стратегії, пов’язані з впровадженням дієвого інклюзивного освітнього середовища, спираючись на багаторічних досвід успішного інклюзивного навчання в інших країнах, відкриває нові горизонти і для української освіти. Так, натомість єдиного означення - «безпечне», - яким на сьогодні характеризується поняття «інклюзивне освітнє середовище» в Україні - у свідомості освітян має бути уявлення про безперешкодне, яскраве, привабливе, підтримувальне, стимулююче середовище, розвивальне для усіх. Саме тоді зміст інклюзивного освітнього середовища не буде зводитися тільки до питання задоволення потреб дитини з ООП, а розширюватиметься до активної участі усіх учнів у розбудові спільного дружнього освітнього простору. Важливо також розуміти, що має бути чіткий план перетворення освітнього середовища (наприклад, план «Класного менеджменту»), що враховує усі важливі його структурні компоненти (предметно-просторові, організаційно-смислові та соціальнопсихологічні ресурси), а також такі характеристики, як персоналізація простору, його змінність, насиченість унікальними для певного класного колективу особистісними смислами.

Скрипник Т., 2020 р. 
Проведене теоретичне та практичне дослідження дало змогу дійти висновку відносно того, що методи та засоби послідовного й продуманого керування освітнім процесом у класі - це пріоритетний напрям сучасної освіти, якому варто приділити велику увагу, адже керування класом передбачає вміння педагогів здійснювати такі дії, які сприяють вирішенню питань порядку у класі й створення умов, сприятливих для повноцінного всебічного розвитку усіх учнів.

Подальше дослідження ми плануємо зробити у таких напрямах, як: розроблення моделі «Інклюзивне освітнє середовище» у закладах загальної середньої і дошкільної освіти, алгоритму іiі впровадження, а також вивчення динаміки змін як наслідку інноваційної діяльності щодо цього конструктивного перетворення освітнього середовища.

\section{Література}

Коваль Л. В. Організація інклюзивного середовища у закладі освіти. Матеріали Міжнародної науково-практичної конферениї «Інклюзивне навчання у Новій українській школі», м. Теребовля. 2018. С. 46-49.

Концепція Нової Української Школи. 2016.2 URL: https://www.kmu.gov.ua/storage/app/media/reforms/ukrainska-shkolacompressed.pdf

Міжнародна класифікація функціонування, обмежень життєдіяльності та здоров'я: МКФ (2018). Дані каталогізації публікацій бібліотечної служби BO3. URL: https://moz.gov.ua/uploads/1/5262-dn_20180523_981_dod_1.pdf

Організаційно-методичні засади діяльності інклюзивно-ресурсних центрів: навчально-методичний посібник / За заг. ред. М. А. Порошенко та ін. Київ: Всеукраїнська благодійна організація «Благодійний фонд Порошенка», 2018. $252 \mathrm{c}$.

Закон України «Про освіту». URL: http://zakon2.rada.gov.ua/laws/show/2145-19/page3 (дата звернення: 03.04.2019).

Скрипник Т. В. Діти 3 аутизмом в інклюзії: сценарії успіху: монографія. Київ: Київський університет імені Бориса Грінченка, 2019. 208 с.

Талдонова Л. О. Інклюзивне освітнє середовище. Теорія $i$ практика сучасної психологіï. 2018. № 6. С. 97-101.

Collier-Meek M. A., Sanetti L. M. H., Boyle A.M. Barriers to implementing classroom management and behavior support plans: An exploratory investigation. Psychology in the Schools. 2018. № 5. P. 5-17. DOI: https://doi.org/10.1002/pits.22127 
Korpershoek H., Harms T., de Boer H., van Kuijk M., Doolaard S. A. Meta-Analysis of the Effects of Classroom Management Strategies and Classroom Management Programs on Students' Academic, Behavioral, Emotional, and Motivational Outcomes. Review of Educational Research. 2019. Vol. 86 (3). P. 643-680. DOI: https://doi.org/10.3102/0034654315626799.

Kumar M., Liu Z. Classroom Management Strategies and Student Learning. Advanced Journal of Social Science. 2019. Vol. 5 (1). P. 65-72. DOI: https://doi.org/10.21467/ajss.5.1.65-72

Wong H. K., Wong R. T., Jondahl S.F., Ferguson O. F. The Classroom Management Book. Denton, Texas: Harry K. Wong Publications, 2014. 308 p.

\section{References}

Koval, L. V. (2018). Organizaciya inklyuzivnogo seredovisha u zakladi osviti [Organizing an inclusive environment in an educational setting]. Materiali Mizhnarodnoyi naukovo-praktichnoyi konferenciyi «Inklyuzivne navchannya u Novij ukrayinskij shkoli», m. Terebovlya, 46-49.

Koncepciya Novoyi Ukrayinskoyi Shkoli [New Ukrainian School Concept]. 2016. https://www.kmu.gov.ua/storage/app/media/reforms/ukrainska-shkolacompressed.pdf

Mizhnarodna klasifikaciya funkcionuvannya, obmezhen zhittyediyalnosti ta zdorov'ya: MKF (2018). Dani katalogizaciyi publikacij bibliotechnoyi sluzhbi VOZ [International Classification of Functioning, Limitations on Life and Health: ICF. Cataloging of WHO Library Service publications]. https://moz.gov.ua/uploads/1/5262-dn_20180523_981_dod_1.pdf

Poroshenko, M. A. (Ed.) (2018). Organizacijno-metodichni zasadi diyalnosti inklyuzivnoresursnih centriv: navchalno-metodichnij posibnik [Organizational and methodological foundations of the activity of inclusive-resource centers: educational-methodical manual]. Blagodijnij fond Poroshenka.

Zakon Ukrainy «Pro osvitu» [The Law of Ukraine on Education] (2017). Retrieved from http://zakon2.rada.gov.ua/laws/show/2145-19/

Skrypnyk, T. V. (2019). Diti z autizmom v inklyuziyi: scenariyi uspihu: monografiya [Children with Autism in Inclusion: Success Scenarios: a Monograph]. Kiyivskij universitet imeni Borisa Grinchenka

Taldonova, L. O. (2018). Inklyuzivne osvitnye seredovishe [Inclusive educational environment]. Teoriya i praktika suchasnoyi psihologiyi, 6, 97-101.

Collier-Meek, M. A., Sanetti, L. M. H. \& Boyle, A. M. (2018). Barriers to implementing classroom management and behavior support plans: An exploratory investigation. Psychology in the Schools, 5, 5-17. https://doi.org/10.1002/pits.22127.

Korpershoek H., Harms T., de Boer H., van Kuijk M. \& Doolaard S. (2019). A MetaAnalysis of the Effects of Classroom Management Strategies and Classroom Management Programs on Students' Academic, Behavioral, Emotional, and 
Motivational Outcomes. Review of Educational Research, 86 (3), 643-680. https://doi.org/10.3102/0034654315626799.

Kumar, M., Liu, Z. (2019). Classroom Management Strategies and Student Learning. Advanced Journal of Social Science, 5 (1), 65-72. https://doi.org/10.21467/ajss.5.1.65-72.

Wong H. K., Wong R. T., Jondahl S. F. \& Ferguson O. F. (2014). The Classroom Management Book. Harry K. Wong Publications.

\section{ПОДГОТОВКА ОБРАЗОВАТЕЛЬНОЙ СРЕДЫ К ИНКЛЮЗИВНОМУ ПРОЦЕССУ В УЧРЕЖДЕНИЯХ ОБЩЕГО СРЕДНЕГО ОБРАЗОВАНИЯ}

Татьяна Скрипник, доктор психологических наук, старший научный сотрудник, профессор кафедры специальной психологии, коррекционной и инклюзивного образования, Институт человека,

Киевский университет имени Бориса Гринченко,

ул. Маршала Тимошенко, 13-Б, 04212 Киев, Украина, t.skrypnyk@kubg.edu.ua

В статье представлена суть иеленаправленной $u$ последовательной подготовки образовательной среды к инклюзивному обучению. Автор раскрывает ограниченный и противоречивый характер понятия «инклюзивная образовательная среда» в украинских нормативно-правовых и учебно-методических разработках; представлены международные ориентиры, по которым образовательная среда приобретает такие характеристики, как: беспрепятственная, стимулирующая, поддерживающая, развивающая для всех учеников. Автор анализирует содержание u структурные компоненты стратегии «Классный менеджмент», что способствуют успеху каждого участника образовательного процесса. Представлено исследование по внедрению стратегии «Классный менеджмент» в образовательный процесс, в котором приняли участие семь образовательных учреждений. Целью исследования было осуществить преобразования в образовательной среде как основы внедрения эффрективного инклюзивного обучения. Полученные результаты показали действенность стратегии «Классный менеджмент», что преобразует образовательную среду и способствует развитию грамотного инклюзивного прочесса.

Ключевые слова: дети с особыми образовательными потребностями, инклюзивная образовательная среда, инклюзивное обучение, классный менеджмент.

\section{PREPARATION OF THE EDUCATIONAL ENVIRONMENT FOR AN INCLUSIVE PROCESS IN THE INSTITUTIONS OF GENERAL SECONDARY EDUCATION}

Tetiana Skrypnyk, Doctor of Science (Psychology),

Senior Researcher, Professor of the Department of Special and Inclusive education,

Institute of Human Sciences, Borys Grinchenko Kyiv University, 13b Marshal Timoshenka Str., 04212 Kyiv, Ukraine, t.skrypnyk@kubg.edu.ua 
This article is devoted to approaches to the targeted and consistent preparation of the educational environment for inclusive learning in educational institutions. The author reveals the limited and controversial nature of the concept of "inclusive educational environment» in Ukrainian regulatory and educational materials; the author presents international guidelines, according to which the educational environment acquires such characteristics as: free, stimulating, supportive, developing for all students. The author carefully analyses the content and structural components of the classroom management strategy (object spatial, organizational-semantic, socio-psychological), aimed at positive transformation of the educational environment for the success of each participant in the educational process. The author presents research on the implementation of the "Classroom Management» strategy in the educational process, in which seven educational institutions took part. The aim of the research was to carry out positive transformations in the educational environment as the basis for the implementation of effective inclusive education. According to expert assessments of the teaching staff, the changes achieved have significantly improved the start of inclusive education. In turn, the team of organizers and experts of this research noted the particular success of two schools, the teaching teams of which showed sincere interest in the proposed approach and joined the preparatory work not as consumers, but as real partners, with enthusiasm, creative proposals, a desire to transform the environment for the better and achieve greater success in student learning and development. The results obtained showed the effectiveness of the "Classroom Management» strategy, which positively transform the educational environment and contribute to the development of a competent inclusive process.

Keywords: children with special educational needs (SEN), classroom management, inclusive education, inclusive educational environment.

Стаття надійшла до редакиії 02.01.2020

Прийнято до друку 27.02.2020

Скрипник Т., 2020 р. 